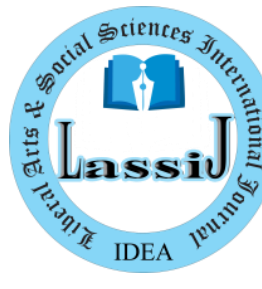

Research Article

ISSN: 2664-8148 (Online)

Liberal Arts and Social Sciences

International Journal (LASSIJ)

https://doi.org/10.47264/idea.lassij/3.2.21

Vol. 3, No. 2, (July-December) 2019, 197-207

https://www.ideapublishers.org/lassij

\title{
Religion and Gender Roles: A Quantitative Study of Women Political Participation in District Charsadda, Pakistan
}

\author{
Shehla Khan ${ }^{1}$, Azizullah Jan* \& Ihsan Ullah Khan ${ }^{2}$ \\ 1. Department of Sociology, University of Peshawar, Peshawar, Pakistan. \\ 2. Department of Sociology, FATA University, FR Kohat, Pakistan.
}

\begin{abstract}
Religion is one of the basic institutions of a society. The study aims to find the religious hindrances faced by women in participating in active politics at district Charsadda, Pakistan. The nature of the study is quantitative, and the questionnaire/interview schedule used is as a tool of data collection for collecting information from the sample size of 130 respondents through simple random sampling. The primary data has analysed in univariate analyses through descriptive statistics to find the frequency and percentages of the data when. The bivariate data has been analysed by applying the Chi-square test in inferential statistics to find the association between dependent and independent the variables. The findings show that in a patriarchal society, the strong religious followers restrict women to household activities only $(\mathrm{P}=0.003)$. The misinterpretation of religion is another factor which keeps women outside politics $(\mathrm{P}=0.001)$. The study recommends that all the institutions should take necessary steps along with the leaders of religious school for building a consensus on women role in politics. They should take the initiative to create awareness about women's participation in politics and their leadership role. It would help improve women's status with a dynamic role in all spheres of life.
\end{abstract}

Keywords: Role of Religion in Politics, Women Role in Politics, Women Political Participation, Women Leadership.

\section{Introduction}

Women are restricted in terms of participation in an active politics as compared to the men in developing societies. Women in government in the cutting-edge period are underrepresented in many nations around the world. In a significant number of these nations, women lacked open doors in the social investment, particularly in taking a stab at political rights and power in the legislature and various foundations. Religion, additionally assumes a significant job in keeping women at home (Begum et al., 2002). About 89\% population of Pakistan is Muslim majority. The practices in Islam are male-centric and are unequivocal regarding the division of works and duty based on sexuality, successfully purifying man strength. As per this training, the male is the worker, and the woman is the wine waiter of the male. In such a way, women are kept in homes due to their roles divided based on sexuality. However, a fallacy over women's status and low performance is still prevalent. The governments at various times have been introducing 
several policy directions through legislation for bringing the women at par domain. Besides, women are still lagging about their level of participation in society and state institutions. Women in the political arena at the grass-root have proved some success. The recent devolution paradigm during General Musharraf regime and afterwards also focuses on the women's participation in the local bodies to mainstream the social fabrics at the grass-root level to ensure women fully participate (Naz, 2012).

Women are told to observe "Purdah" when willing to go outside their houses, with the purpose to cover themselves from others. Other types of persecution and brutality against women in developing Muslim societies have surfaced due to the emergence of fundamentalism and extremism. The instances of the mistreatment of women in the rural areas because of fatwas by mullahs are considerably expanding. In addition, religious fundamentalism has become more grounded in the prevailing political landscape over the years. Successive governments have nurtured the development of this power for their specific interests. According to Mukhopadhyay (1999), girls were socialized to be mothers, wives, and workers under others' power. Their household tasks are infinite; even when young, they typically help at home and take care of younger siblings, and the middle-class families using maidservants expect the women to bring along their daughters to help. Yet, despite this hard and continuing labour, women are, always perceived as weaker than men, which in turn, justify "protectiveness" and unwillingness to let women go out of the house. In most countries, the discrimination between men and women is marked by culturally fostered strict differences in dress and behavioural patterns. Customs of "Purdah" exist not only among the Muslims, but also among Hindus in rural India, where women in more "respectable caste" outmoded families are required to cover their faces before men, and Sari ends are worn over the head, sometimes covering the face. Women sidestep the attendance of non-kin males.

Religious fundamentalism promotes this Purdah behaviour with continuous efforts to retain women out of the public and social life. Fundamentalists of all classes have attacked women following new "revealing" fashions. Overall, the religious fundamentalism is an unfavourable factor to the women taking part in politics. However, through the political participation of women, it can easily encourage and allow women to address their issues and solve them according to their wishes and desire. However, this matter of fundamentalism and religious extremism has to be analyzed by noting that the women represent themselves within these movements too. Moreover, at the broader political level, the "religious" parties of South Asia including Pakistan have some women representation. For instance, the prime minister of Bangladesh belongs to the more Islamist-identified of the two major political parties, while in India; the Hindu-nationalist Bharatiya Janata Party has two women among its chief ministers. The secular Communist parties, distinctly, have no high-level political participation by women, except for a recent induction of one woman into the politburo of the Communist Party of India (Hardgrave, 1993; Simelyte, 2010).

Political investment probably is one of the significant components of strengthening mindfulness and cognizance among women about their privileges in the public. It guarantees power and solidarity to the women to pick those leaders who have the capacity or expertise about women related issues and can lessen gender discrimination. In addition, it offers an opportunity for women to choose those leaders who realize how to tackle their urgent issues and to address the gender discrimination issues (Mahmood, 2010). However, in Pakistani society and particularly the rural territories in Pakhtun society, women are discouraged generally and have no participation in the political sphere and strengthening administrations 
(Naz, 2012). The political cooperation of women and women's strengthening is interconnected. Through, the political interest of women can urge the women without much of a stretch to address their issues and explain them as per their desires and want (Mahmood, 2010). The interest of women in legislative issues is lower than guys, however, the Pakistani ladies' situation in governmental issues is urging when contrasted with different nations. The interest of women of Pakistan in governmental issues is on the 50th situation on the planet positioning request (Hausmann et al., 2009).

As per Stromquist (1995), political interest is essential for women strengthening in the society as political help overhaul limitation of working among the women to administer, separate, and actuate resources for the social change. Another examination directed by Oxaal and Baden (1997) shows the same findings on their contiguous issues. Batliwala (1995) shows that the majority rules system assumes a critical part in raising the political mindfulness among the masses. Without majority rule in political frameworks, the cycle of strengthening is deficient. Chandra (1997) favours the political cooperation of women at the grass-root level, which can be useful for redesigning the females' positions and enabling them. Additionally, to give and build up a decent political culture for women, attempts should be made to augment political mindfulness among women at the close-by level. It can add weightage to social events of women for dealing with their related issues at the local level and demonstrate their critical issues at a higher level.

Leadership is a very castoff word and can have numerous aspects concerning period and space. Diverse theorists, intellectuals, and academicians have hypothesized this term consequently. These theories describe different aspects of leadership from various perspectives; such as psychological, sociocultural, political, and biological. Leadership itself is a broad nature idea and there are multiple concepts and classes of leadership present. Women's leadership is simply one outlet of the notion and can also be described in different methods (Jan et al., 2020). Because, some recognize women leadership as a fact that enables females to be a leader, while other researchers explain it from an activist perspective and as a matter of egalitarianism and the right to have similar opportunities. Several studies stated that it refers to specific feminine features that are valued in today's organizational structure. Whereas others think that leadership would not be discriminated against based on female leadership at all. It is culturally required as variations occur over time, so it is tough to give one meaning of it that spreads over to all the leadership. On the other hand, to realize the concept of female leadership and its vital scope will be enlightened further (Palmu-Joronen, 2009).

Social standards work as both a limitation on a women's versatile nature and a hindrance to her interest in the general population circle. These social standards are propagated and continued by the ground-breaking foundations of family, position, and religion and affect sexual orientation related issues. According to the Center for Asia-Pacific the strengthening of women regarding access to basic leadership positions is significantly influenced by social generalizations that exist in many social orders. In the Asia-Pacific locale, the real types of social generalizations incorporate; (1) that ladies' essential duty is to deal with the family and kids, and it is just an optional commitment to get engaged with social and political foundations; (2) that ladies need more understanding, and in this manner are not fit for accepting administrative positions, (3) that the general population space is primarily for men, while the private family area is for ladies, and (4) that ladies' contribution in people in general circle ought to be an expansion of their jobs in the family circle. Such sexual orientation generalizations are established in social standards as Bangladesh isn't a special case in such a 
manner. There is a truism in Bangladeshi culture that "A women's heaven is at the feet of her significant other." Women who trust this are usually less inclined to oppose conjugal brutality or get associated with exercises outside the home (Solotaroff \& Pande, 2014).

The conventional male-centric culture of South Asian states depends on the class and sexual orientation divisions. Class portability permits the development among the rich and poor. However, the division of social space and the distinction in conduct standards among people are inflexibly kept up. The family, which comprises the fundamental unit of social association and control, sets the standards for male and female jobs. Inside this framework, the dad, or in his nonappearance, the following male kinfolk, is the leader of the household. Therefore, both basic leadership powers and monetary control are vested in the hands of men. Moreover, the family works through a characterized arrangement of rights and commitments. This is exhibited when Muslim women defer the privilege to acquire their dads' property for siblings or, in case of acquiring property, pass control to their spouses or children. In the two cases, the man offers security to the woman as an end-result of command over her property, in this manner specifically fortifying a man-centric custom. A spouse frequently compromises his better half with separation on the off chance that she declines to deal with her little girl and make sure that she weds the husband he has chosen for her. In the outrageous patriarchal culture, a mother must persuade her little girl if she differs from something the dad requests, as women do not have the privilege to choose whom to wed (Norris, 2013).

Rosaldo (1974) portrays female's subjection as a recorded marvel. Since old times, female mediocrity has been conspicuous in the social orders where there is an unmistakable part between private and public life and where females are confined to house. Notwithstanding numerous ladies' developments attempting to battle for ladies' rights in the third world, females in the third world nations are as yet denied of their privileges to settle on their own choices, choose their life, and pick the vocation they need, and assemble a dream. As per Albertyn (2009), in South Africa and comparative nations, although laws of fairness have just been passed to make sure about equivalent privileges of females, yet these laws are most certainly not pertinent in broad daylight and private life. Guys have control over the majority of the land, property, and network regardless of equivalent property rights. Culture is a positive acknowledgment and in figuring out the world by bringing up significant issues about the nature of and relationship between our standards and practices (Ielics \& Runcan, 2012). Although majority rules system wins in these social orders and their constitution depends on equivalent women rights and equity of sex, these parts of the constitution are neglected and barely followed due to pervasiveness of exacting male prevailing society which doesn't permit specialists to meddle between a male and female's relationship (Ielics \& Runcan, 2012). Culture is characterized as the specific lifestyle of individuals which envelops the qualities these individuals hold (Rosaldo, 1974). Culture is given high significance and is implanted in individuals of a specific gathering; it is a method of figuring out the world and a casing of reference for individuals of specific gathering (Wirth, 2001).

\section{Theoretical Framework}

The socialist feminist theory is on the same page as the present study. This theory accentuates the oppression of women in male-dominant societies, as the disparity is class-based. Women work the same as men; men work outside and earn money while women work inside the house. They raise and take care of their children with domestic responsibilities. Socialist feminism is based on the interests and political rights of the oppressed segment of the society, which 
becomes more oppressed in workplaces due to capitalism. Here, the role of the oppressor is played by the male member, while women face oppression in each aspect of life. The slogan of feminism is 'the political is private' highlighted that the women subservient in everyday life at all level is due to their political participation and action (Barrett \& Mclntosh, 2005).

\subsection{Glass Ceiling Theory}

The notion of glass ceiling instigated in the US, wherever the central Glass Ceiling Commission was formed as portion of the United States Act of Civil Rights, 1991 to convey a survey and afford suggestions to the United State Congress to demolished the hindrances faced by the women on high positions (Insch et al., 2008). According to Insch et al. (2008), the Glass Ceiling Commission (GCC) found that females were being appointed into feminized places in the business. Additionally, it also came to the surface that the male members in the businesses or organizations opposed the senior positions for women. According to Meyerson and Fletcher (2000), within the organizations, there are usually gender gaps and non-equality in their status and dignity. They talked about the systematic blocks which stop the advancement of women even if men and women have the same abilities.

According to Powell and Butterfield (2003), the glass ceiling is a hurdle so restrained and apparent, so far so sturdy that it escaped the subordinated group and women from the hierarchy of management moving. Dissimilar to formal obstructions to professional success, for example, absence of training and inadequate work understanding, the shade of the roof indicates that irrational impairment hindrances are less distinctive and might be mounted in culture; society, and mental components that work on the whole to hinder the progress of females to senior administrative positions. This glass ceiling theory is quite related to the study matrix, where it shows the male dominancy in the organization where they did not want to give way to the progress and success of women in different organizations. In the same way, in a patriarchal society, they also did not want to allow women to participate in different outdoor activities and become a success. The Pakhtun society is also male dominant where the male members do not allow women to participate in politics as this theory confronts the face of the patriarchal system in district Charsadda that opposes the females' participation in politics.

\subsection{Liberal Feminist Theory}

The liberal feminist theory is very important to this study because liberal feminist theory focuses on the rights and strengths of the female as compared to the difference between the two sexes (male and female) (Parrish, 2014). According to the liberal feminism theory, in patriarchal societies, they have their hold over the female members as the male members think that equality of both the sexes is a challenge for patriarchy (Kivoi, 2014). Liberal feminism theory focuses on cramping gender roles in their socialization in the restricted male-dominant culture for females. Liberal feminists want the oppressive women to be aware of their low selfesteem, anxiety, fear of success, and low confidence in taking participation in politics (Worrel, 2002). As in a Pakhtun society, the socialization pattern supports the male members and considers them "son as a gun". Through this quote and the restricted culture, it is very difficult for females to participate in politics like men (Kivoi, 2014).

\section{Material and Methods}

This quantitative study is conducted in $75 \%$ union councils in three Tehsils of district Charsadda. 
The respondents comprised of those women who had contested local government elections in the targeted district. The primary facts were collected through a simple random sampling technique where the total population was 196 in the target area of the study. From the total population, a sample size of 130 councillors was taken through Sekaran's (1983) sample size table. The secondary data shows that 196 women had contested the local body elections in the study area. The total sample size was distributed to various Union Councils on a proportionate basis. To obtain the prime data interview schedule was developed in light of the objectives and different variables discussed in the literature review. To check the relevancy and reliability, the tools for data collection were pre-tested.

The interview schedule was used because; all of the respondents were not educated and were not able to have sufficient understanding about the depth of the questions to solve by themselves. After the collection of the primary data the researcher analyzed the empirical data through Statistical Package for Social Sciences (SPSS). The data was analyzed in two phases. In the first phase of the analysis, the frequency and percentages have come out through descriptive statistics. Univariate and bivariate data were analyzed by applying the Chi-square test to see the association level between independent (educational, socio-cultural, gender stereotyping, religion, and familial) and dependent variables (women participation in active politics) in inferential statistics. The primary facts were analyzed through using proper statistical techniques i.e., univariate and bivariate level respectively. The bivariate level, Chi-square $\chi^{2}$ test has been used to determine the relationship between the dependent variable (women participation in active politics) and independent variables (educational roles) as outlined by McCall and Robert (1975).

\section{Analysis and Discussion}

This section gives a detailed account on the results, analysis and discussion on the univariate and bivariate analysis in detail.

\subsection{Univariate Analysis}

Every society is based on five fundamental social institutions that are family, school, government, religion, and economics. In addressing the dynamic governmental issues, resolving the issues of each gender features most significantly. Women support in the governmental issues helps to advance gender balance and influences both the scope and strategy that are thought of along with the proposed arrangements. The studies show that whether an official is male or female, it distinctly affects their strategy and needs. Likewise, there are evidences that as more women are chosen for the office, there is a product increment in strategy making that underlines personal satisfaction and mirrors the needs of families, women, and the ethnic and racial minorities. The data in the table-1 is related to women's participation in politics in the light of religion. In the first statement the majority of the respondents, i.e., 56.2 percent did not agree with the statement that religion restricts women to household activities only. Some of the sampled population i.e., 22.3 percent did not share their opinion and 21.5 percent agreed with the statement that yes, religion restricts women to household activities.

In the second statement majority of the respondents, i.e., 76.2 percent agreed that yes, the misinterpretation of the religion keeps women outside of the politics while 13.8 percent of respondents did not agree and 10.0 percent did not show their opinion regarding the statement 
that misinterpretation of religion keeps women outside of the politics. Furthermore, a large number of the respondents i.e., 68.5 percent did not agree with the statement that Purdah resists women's participation in the elections and other political activities. Some of the respondents i.e., 20.0 percent agreed to the statement and 11.5 percent of respondents did not know about the statement. Moreover, the majority of the respondents i.e., 70.0 percent believed that strong religious followers also participate in politics whereas 20.8 percent of respondents were against the statement and the rest of the respondents i.e., 09.2 percent did share their views. In the last statement of the variable majority of the respondents, i.e., 61.5 percent agreed that women's leadership in Pashtun society is considered shameful and sinful due to the misinterpretation of religion. Some of the respondents i.e., 28.5 percent did not agree while 10.0 percent of respondents did not share their opinions regarding the statement.

Table 1: Women Participation in Politics in the light of Religion

\begin{tabular}{|c|c|c|c|c|c|c|c|c|}
\hline No. & Statements & \multicolumn{2}{|c|}{ Yes $(\%)$} & \multicolumn{2}{|c|}{ No $(\%)$} & \multicolumn{2}{|c|}{ Neutral (\%) } & Total \\
\hline 1 & $\begin{array}{l}\text { Religion restricts women to household } \\
\text { activities only }\end{array}$ & 28 & 21.5 & 73 & 56.2 & 29 & 22.3 & 130 \\
\hline 2 & $\begin{array}{l}\text { The misinterpretation of religion keeps } \\
\text { women outside of the politics }\end{array}$ & 99 & 76.2 & 18 & 13.8 & 13 & 10.0 & 130 \\
\hline 3 & $\begin{array}{l}\text { Purdah (veil) resist/hinder women } \\
\text { participation in elections/other political } \\
\text { activities }\end{array}$ & 26 & 20.0 & 89 & 68.5 & 15 & 11.5 & 130 \\
\hline 4 & $\begin{array}{l}\text { Strong religious followers participate in } \\
\text { politics }\end{array}$ & 91 & 70.0 & 27 & 20.8 & 12 & 09.2 & 130 \\
\hline 5 & $\begin{array}{l}\text { Women's leadership in Pashtun society is } \\
\text { considered shameful and sinful due to the } \\
\text { misinterpretation of religion. }\end{array}$ & 80 & 61.5 & 37 & 28.5 & 13 & 10.0 & 130 \\
\hline
\end{tabular}

Table values in each cell indicate frequency while the value of parenthesis indicated percentage.

\subsection{Bivariate Analysis}

The significant support of women in public, nearby, and network positions of authority in the society has become a significant spotlight on the worldwide improvement strategy. In any case, some may inquire as to why it is important if women become political leaders, chosen policymakers, or common society activists. For what reason does the world need more women engaged with all parts of the political cycle? Women political investment by any nation brings about substantial value additions for the participatory rules system, including more prominent responsiveness to resident needs, expanded participation across gathering and ethnic lines, and a more sustainable and prosperous future.

Findings in the table-2 indicate the association between religious followers in Pashtun society and women's participation in politics. The religion restricts women to household activities where a significant association $(\mathrm{P}=0.003)$ was observed with women participation in politics and, a significant association $(\mathrm{P}=0.001)$ was found between the misinterpretation of religion that keeps women outside of the politics and women active participation in politics. Also, a significant association $(\mathrm{P}=0.033)$ was seen between the statements that the Purdah/Veil resists the women participation in the election and other political activities with the statement that the women are participating in politics in the Pashtun social structure. Furthermore, it could be deduced from the data that there existed a highly significant association $(\mathrm{P}=0.000)$ between the strong religious followers participate in politics with the women participate in politics. The statement results showed that in Pakistan, especially in Pashtun society, the strong followers 
of religion also participated in politics. This statement fully negates the opinion of Naz (2012) that in our country Pakistan, women in rural areas are restricted from casting their vote for the resolution of their problems. In the last statement of the variable, a significant association $(\mathrm{P}=0.001)$ was observed between women leadership in Pashtun society is considered shameful and sin due to misinterpretation of religion with women participation in the politics. It shows that in a male-dominated society like in Pashtun culture, the women are considered shameful to take part in politics.

Table-2: Association between Religious Followers and Women Participation in Politics

\begin{tabular}{|c|c|c|c|c|c|c|}
\hline \multirow{2}{*}{\multicolumn{2}{|c|}{ Statements }} & \multicolumn{3}{|c|}{ Women Participation in Politics } & \multirow{3}{*}{$\begin{array}{l}\text { Total }(\%) \\
28(21.5)\end{array}$} & \multirow{2}{*}{$\cdot \stackrel{0}{\tilde{n}}$} \\
\hline & & Yes $(\%)$ & $\mathrm{No}(\%)$ & Neutral $(\%)$ & & \\
\hline \multirow{4}{*}{$\begin{array}{l}\text { Religion restricts women to } \\
\text { household activities only }\end{array}$} & Yes & $10(7.7)$ & $17(13.1)$ & $01(0.8)$ & & \multirow{4}{*}{ 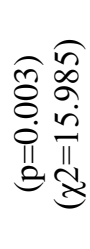 } \\
\hline & No & $36(27.7)$ & $36(27.7)$ & $01(0.8)$ & $73(56.2)$ & \\
\hline & Neutral & $17(13.1)$ & $07(5.4)$ & $05(3.8)$ & $29(22.3)$ & \\
\hline & Total & $63(48.5)$ & $60(46.2)$ & $07(5.4)$ & $130(100)$ & \\
\hline \multirow{4}{*}{$\begin{array}{l}\text { The misinterpretation of } \\
\text { religion keeps women } \\
\text { outside the politics }\end{array}$} & Yes & $50(38.5)$ & $46(35.4)$ & $03(2.3)$ & $99(76.2)$ & \multirow{4}{*}{ 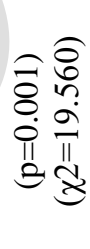 } \\
\hline & No & $10(7.7)$ & $08(6.2)$ & 00 & $18(13.8)$ & \\
\hline & Neutral & $03(2.3)$ & $06(4.6)$ & $04(3.1)$ & $13(10.0)$ & \\
\hline & Total & $63(48.5)$ & $60(46.2)$ & $07(5.4)$ & $130(100)$ & \\
\hline \multirow{4}{*}{$\begin{array}{l}\text { Purdah/Veil resist/hinder } \\
\text { women participation in } \\
\text { elections/other political } \\
\text { activities }\end{array}$} & Yes & $10(7.7)$ & $14(10.8)$ & $02(1.5)$ & $26(20.0)$ & \multirow{4}{*}{ 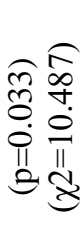 } \\
\hline & No & $50(38.5)$ & $34(26.2)$ & $05(3.8)$ & $89(68.5)$ & \\
\hline & Neutral & $03(2.3)$ & $12(9.2)$ & 00 & $15(11.5)$ & \\
\hline & Total & $63(48.5)$ & $60(46.2)$ & $07(5.4)$ & $130(100)$ & \\
\hline \multirow{4}{*}{$\begin{array}{l}\text { Strong religious followers } \\
\text { participate in politics }\end{array}$} & Yes & $50(38.5)$ & $40(30.8)$ & $01(0.8)$ & $91(70.0)$ & \multirow{4}{*}{ 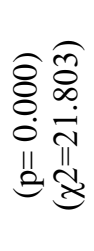 } \\
\hline & No & $09(6.9)$ & $12(9.2)$ & $06(4.6)$ & $27(20.8)$ & \\
\hline & Neutral & $04(3.1)$ & $08(6.2)$ & 00 & $12(9.2)$ & \\
\hline & Total & $63(48.5)$ & $60(46.2)$ & $07(5.4)$ & $130(100)$ & \\
\hline \multirow{4}{*}{$\begin{array}{l}\text { Women leadership in } \\
\text { Pashtun society is } \\
\text { considered shameful and sin } \\
\text { due to misinterpretation of } \\
\text { religion }\end{array}$} & Yes & $40(30.8)$ & $39(30.0)$ & $01(0.8)$ & $80(61.5)$ & \multirow{4}{*}{ 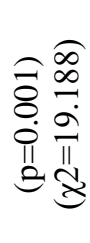 } \\
\hline & No & $18(13.8)$ & $17(13.1)$ & $02(1.5)$ & $37(28.5)$ & \\
\hline & Neutral & $05(3.8)$ & $04(3.1)$ & $04(3.1)$ & $13(10.0)$ & \\
\hline & Total & $63(48.5)$ & $60(46.2)$ & $07(5.4)$ & $130(100)$ & \\
\hline
\end{tabular}

These findings were in resemblance to those of Jan et al. (2020), as according to them, Islamic practices are patriarchal and only the male is considered as the owner of the family. On this basis the division of labour exists in the society like, women will be at home, she will play the role of the server and, males will play the role of the owner. The previously mentioned finding also negates the views of $\mathrm{Naz}$ (2012) that women issues are bitterly highlighted by women rather than men and, in such a way, women are easily encouraged to participate in the political 
activities of a nation. These results also supported findings of Durkheim (2013) in his classic work, the division of labour. According to Emile Durkheim, every person is born for a particular work, so it means that the women are born for indoor work while men are born for outdoor activities. Some women take part in the political activities; though they are not banned by the religion, yet the patriarchal social structure did not allow them to participate in the politics and other outside social and political activities. These things just misinterpret the narrow mindset and ignorant religious leaders in Pashtun society. Furthermore, according to Shamim and Nasreen (2002) and Shehabuddin (1999), strong religious followers participate in political activities like, in Pashtun society, most of the Pashtun religious leaders participate in politics. Purdah did not play the role of resistance against the participation of women in politics; male dominancy is the main cause to resist the females, instead. In simple words, the maledominant society did not want the females to participate in politics, specifically in Pashtun society. Their participation in politics and leadership activities are regarded as a sin and shameful for their integrity.

\section{Conclusion}

This study concluded that participating in the public affairs and active participation in politics like addressing a crowd on the part of the women is still being treated as a taboo in the Pashtun society. The findings also highlighted that women are restricted to the household activities by the social structure and culture of the society. Some of the social sentiments, cultural norms and religious restrictions have also limited the role of women in the society especially the political participation. These sentiments are related to Purdah for women and, going against them is regarded as an act of shamefulness for the family. Some agents of society misinterpret the participation of women in leadership activities too. The study recommended that all the institutions of society should take the initiative to produce awareness about women's leadership and political participation. That would help improve women's status in society with a dynamic role to play in all spheres of life.

\section{References}

Albertyn, C. (2009). The Stubborn Persistence of Patriarchy. Gender Equality \& Cultural Diversity in South Africa, 2, 165-208. https://journals.co.za/doi/pdf/10.10520/EJC28139

Barrett, M., \& McIntosh, M. (2005). Ethnocentrism and Socialist-feminist Theory. Feminist Review, 80(1), 64-86. https://doi.org/10.1057\%2Fpalgrave.fr.9400224

Begum, A., Ayesha, \& Ghauri, (2002). Dimensions of Women Empowerment: A Case Study of Pakistan. Dimensions, 6(1). 26-41. https://www.researchgate.net/publication/319099845

Batliwala,S.(1995). Defining Women Empowerment; A Conceptual Frame Work. In: Education for Women Empowerment. Position paper for the fourth world Conference on Women, Beijing. ASPBAE, 54-57.

Chandra, S. K. (1997). Women and Empowerment. Indian Journal of Public Administration, 43(4), 395-99.

Hardgrave, R. L. (1993). The Challenge of Ethnic Conflict in India: The Dilemmas of Diversity. Journal of Democracy, 4(4), 54-68. https://doi.org/10.1353/jod.1993.0052

Hausmann, R., Zahidi, S., Tyson, L., Hausmann, R., Schwab, K., and Tyson, L. D. A. (2009). 
The Global Gender Gap Report. World Economic Forum. http://www3.weforum.org/docs/WEF_GenderGap_Report_2009.pdf

Ielics, B., \& Runcan, P. L. (2012). The Profile of the Successful Woman Manager in Romania. Procedia-Social \& Behavioural Sciences, 4(6), 909-911. https://doi.org/10.1016/j.sbspro.2012.05.222

Insch, G. S., McIntyre, N., \& Napier, N. K. (2008). The Expatriate Glass Ceiling: The Second Layer of Glass. Journal of Business Ethics, 83(1), 19-28. https://link.springer.com/article/10.1007/s10551-007-9649-0

Jan, A., and Khan, I. U. (2020). The Participation of Women in Politics in Respect of Religion:

A Case Study of Charsadda District of Khyber Pakhtunkhwa, Pakistan. Bannu University Research Journal in Islamic Studies (BURJIS), 7(1), 19-26. http://www.ustb.edu.pk/burjis/images/June_2020/English\%202.pdf

Kivoi, D. L. (2014). Factors Impeding Political Participation and Representation of Women in Kenya. Humanities and Social Sciences, 2(6), 173-181. http://www.sciencepublishinggroup.com/journal/paperinfo.aspx?journalid=208\&doi $=10.11648 /$ j.hss. 20140206.15

Meyerson, D. E., \& Fletcher, J. K. (2000). A Modest Manifesto for Shattering the Glass Ceiling. Harvard Business Review, 78(1), 126-136. https://hbr.org/2000/01/amodest-manifesto-for-shattering-the-glass-ceiling

Mahmood, T. (2010). Socio-cultural Determinants of Women Studies. Ph.D. Thesis, Department of Rural Sociology, University of Agriculture Faisalabad.

Mukhopadhyay, M. (1999). Mainstreaming Gender or "Streaming" Gender Away: Feminists Marooned in the Development Business. In: Harcourt W. (eds). The Palgrave Handbook of Gender and Development (pp.77-91). Palgrave Macmillan. https://doi.org/10.1007/978-1-137-38273-3_6.

MCcall, P., \& Robert, B. (1975). Fundamental Statistic for Psychology (2 ${ }^{\text {nd }}$ edition). Harcourt Brace Jovanovich.

Naz, A., \& Ahmad, W. (2012). Socio-cultural Impediments to Women Political Empowerment in Pakhtun Society. Academic Research International, 3(1), 163-164. http://www.savap.org.pk/journals/ARInt./Vol.3\%281\%29/2012\%283.1-21\%29.pdf

Norris, P. (2013). Women's legislative participation in Western Europe. In Women and Politics in Western. Routledge.

Oxaal, Z., \& Baden, S. (1997). Gender and Empowerment: Definitions. Approaches and Implications for Policy, BRIDGE Report, (40). Bridge, Institute of Development Studies, University of Sussex.

Palmu-Joronen, A. L. (2009). Nokia Years What you can Learn from Leadership (Nokiavuodet. Mita Johtamisesta voi Oppia. Jyvaskylä. Atena Kustannus Oy.). https://www.goodreads.com/book/show/43374086-nokia-vuodet-mit-johtamisestavoi-oppia

Parrish, J. K. (2014). Next Steps for Citizen Science. Science, 343(6178), 1436-1437. https://doi.org/ 10.1126/science.1251554

Powell, G. N., \& Butterfield, D. A. (2003). Gender, Gender Identity, and Aspirations to Top Management. Women in Management Review. https://www.emerald.com/insight/content/doi/10.1108/09649420310462361/full/ht $\underline{\mathrm{ml}}$

Rosaldo, M. Z. (1974). Woman, Culture, and Society: A Theoretical Overview. In M. Z. Rosaldo \& L. Lamphere (Eds.), Woman, culture and society (pp. 17-42). Stanford University. 
Simelyte, A. (2010). The Influence of State's Capital Structure on Economic Growth. Mokslas-Lietuvos Ateitis/Science-Future of Lithuania,2(2), 90-96. https://doi.org/10.3846/mla.2010.040

Sekaran, U. (1983). Methodological and Theoretical Issues and Advancements in Crosscultural Research. Journal of International Business Studies, 14(2), 61-73. https://doi.org/10.1057/palgrave.jibs.8490519

Stromquist, N. P. (1995). Romancing the State: Gender and Power in Education. Comparative Education Review, 39(4), 423-454. https://doi.org/10.1086/447339

Shamim, I., \& Nasreen, M. (2002). Gender and Local Governance: A New Discourse in Development. Journal of Social Studies-Dhaka, 94/95, 50-87.

Shehabuddin, E. (1999). Contesting the Illicit: Gender and the Politics of Fatwas in Bangladesh. Signs: Journal of Women in Culture and Society, 24(4), 1011-1044. https://doi.org/10.1086/495401

Solotaroff, J. L. \& Pande, R. P. (2014). Violence against Women and Girls: Lessons from South Asia. South Asia Development Forum: World Bank Group. https://openknowledge.worldbank.org/bitstream/handle/10986/20153/97814648017 $\underline{16 . p d f}$

Wirth, L. (2001). Women in Management: Closer to Breaking Through the Glass Ceiling. In M. F. Loutfi (Ed.), Women, Gender, and Work: What is Equality and How do we Get there (pp. 239-249). Geneva: International Labour Office.

Worrel, P. F. (2002). U.S. Patent No. 6,378,636. Washington, DC: U.S. Patent and Trademark Office. https://www.uspto.gov/patents 